\title{
Husam Zaki Darwish, 1945-2002
}

On 16 March 2002, Canada lost one of its most dedicated, knowledgeable and least appreciated academic pediatric neurologists. I lost my best friend and the colleague with whom I worked more closely than any other over 12 years at Alberta Children's Hospital and the University of Calgary Faculty of Medicine.

I first met Sam in Toronto in 1975, at the first congress of the International Child Neurology Association. His insightful and pointed, rather than argumentative, questions about one of my posters, and his keen wit and engaging personality led to a close personal friendship and professional camaraderie. Many residents have enjoyed listening to our subsequent spirited debates over issues of diagnosis and management of patients. Sam and I confessed to each other that we enjoyed this sparring before an audience of colleagues and trainees, perhaps even more than they did. I recruited Sam to an academic post at St. Louis University in St. Louis, Missouri, positions that did not work out well for either of us. He later assisted Bob Haslam in recruiting me to Calgary, where I spent 12 of the happiest years of my life working with Sam on a daily basis and enjoying the company of his family, his lovely wife Bobbi and his daughters, Amy and Laila. Those years of Sam, Bob Haslam and me working together were rich years for all of us in Pediatric Neurology at Alberta Children's Hospital.

Of the several personal qualities of character that I would attribute to Sam, I offer one or two examples of each.

Loyalty. Above all, Sam was uncompromisingly and fiercely loyal to his family, friends, colleagues, nurses, EEG technologists and other staff. He was very loyal to the institutions he served and to the place that had given him a better life than he might have enjoyed elsewhere. Despite disappointments in the level of support he received at times, he remained in Calgary to serve the pediatric neurological needs of the community. His unique dedication and contributions are well-appreciated by those who worked with him, by the physicians who referred patients to him, and especially by the patients and their families that he served so unselfishly.

Generosity. If generosity is regarded as a virtue in Heaven as we believe it is, Sam already has been awarded a free ticket in the first class section to arrive on that airliner. Sam treated everyone as if they were a VIP and his personal guest. If fortunate enough to be a guest of him and Bobbi in their home, one really understood the meaning of generosity and hospitality as provided by Sam. On the professional side, the generosity of his time and efforts to his patients and to the hospital never received the institutional recognition that they deserved, though patients certainly recognized this quality. Ask any mother whose child had a seizure at 3:00 a.m. and was being cared for by Sam at that hour in the Emergency Room, even though he himself was sleep-deprived and ill. This generosity to his patients continued to the last days of his life, and perhaps even contributed to his premature death, but Sam would not have changed his style, indeed his philosophy of life, even had he known of his impending catastrophe. The large number of patients and parents that attended Sam's funeral are testimony of their appreciation of his generosity and his genuine concern for their health. Sam was generous with his gifts, but most of all with his time, one of the most precious of possessions. This generosity was well-appreciated by the many residents who passed their Royal College examinations in large part because of the time Sam devoted preparing them, for no personal return except satisfaction when they passed.

Fairness. Sam was one of the fairest people I have known, always giving others the benefit of the doubt if there was room for doubt. $\mathrm{He}$ was extremely sensitive of the feelings of others, even when they did not reciprocate this sensitivity. He and I used to repeatedly joke, halfseriously, that if the Israeli-Palestinian conflict could be taken from the politicians of the Middle East and given to Sam and me to resolve, we could craft a solution that would be fair to both sides and preserve dignity for both. Sam was a Palestinian born in Jerusalem and raised in

Palestine and Lebanon; he married a Canadian Jewish girl from Ontario. I have no doubt that Sam was right: he could have resolved the main issues fairly because Sam was that kind of man.

Determination. Sam had a professional "mission" to create academic excellence at Alberta Children's Hospital, and he worked for a quarter century to achieve this goal, not for vanity or personal recognition, but because he felt it his duty to his profession and his colleagues. He succeeded. Despite a lack of sufficient resources that he had earned and were withheld from him to divert to other purposes, Sam developed one of the finest Pediatric Neurology teaching and patient care services in Canada. He developed one of the first laboratories for EEG 
telemetry and pioneered the introduction of studies required for epilepsy surgery. Sam was a superb clinician with diagnostic skills and clinical judgement unsurpassed. He also contributed greatly to the development of his specialty nationally, organized symposia, arranged for many visiting professors in Calgary and at the Canadian Congress of Neurological Sciences. He was a strong and consistent advocate for Pediatric Neurology with his colleagues in other disciplines of Pediatrics and in adult Neurology. He served on the Editorial Board of the Canadian Journal of Neurological Sciences and contributed many excellent papers to the medical literature. His research was important to him and he did it well, managing to execute well-planned studies despite a very heavy and continuous load of clinical care and teaching commitments. He sacrificed his own academic advancement in the interest of the needs of his patients and the education of his residents and students.

Wit. Sam's keen sense of humor is legendary amongst his colleagues and friends. At times he had a biting irony in what he said, but his satire always had a profound truth as its basis. His witty jokes revealed his intellect and insight into people and their motives, both honorable and otherwise.

Gentleness. Despite his ample physical size, Sam was one of the gentlest and kindest individuals I have ever had the privilege of knowing. He was a true "teddy bear", as any of his small patients, his nurse Val Lange, his secretary Lydia, his friends, his daughters and, most of all, his wife Bobbi, will affirm.

A few years ago, Sam gave me a gift of an original oil painting of Banff National Park. I have treasured this painting for the friendship of Sam that it represents even more than the attractive view that it faithfully portrays, and it has hung in a prominent place on the wall of my home since that time, and always will. I admired and respected Sam greatly. My small gratification is that I had the presence of mind to tell him this just a couple of years ago. My regret is that I cannot tell him just one more time.

Harvey B. Sarnat Calgary, Alberta and Los Angeles, California 